\title{
Fine root traits in adult trees of evergreen and deciduous taxa from low and high elevation in the Alps
}

\author{
Pilar Alvarez-Uria · Christian Körner
}

Received: 5 September 2010/Revised: 14 March 2011 / Accepted: 9 July 2011 / Published online: 26 July 2011

(c) Swiss Botanical Society 2011

\begin{abstract}
Based on evidence for herbaceous plants we expected that trees become more efficient in terms of soil exploration by roots and, thus, produce longer and finer roots (higher specific root length, SRL) with increasing elevation. We tested this hypothesis in situ by excavating roots of eight tree taxa, all belonging to genera found frequently in both lowland and high elevation sites. Across three treeline, one montane and four lowland sites from elevations ranging from 320 masl to 2,235 masl, no elevational differences were found in SRL for both broadleaved and conifer tree species. Irrespective of the elevation preference of a species, SRL of evergreen conifers was significantly lower than that of deciduous species. However, there is an increase in total root length for a given 3rd order root diameter with elevation in the broadleaved taxa. Our findings clearly demonstrate that a high SRL is not an essential attribute of trees growing in a cold high elevation climate in temperate regions, but there is some indication that fine roots get longer as elevation increases.
\end{abstract}

Keywords Altitude - Specific root length - Temperature . Conifer $\cdot$ Deciduous $\cdot$ Alps

\footnotetext{
P. Alvarez-Uria · C. Körner

Institute of Botany, University of Basel,

Schönbeinstrasse 6, 4056 Basel, Switzerland

e-mail: ch.koerner@unibas.ch

Present Address:

P. Alvarez-Uria $(\square)$

Spanish Observatory of Sustainability,

University of Alcala, Plaza de San Diego,

s/n 28801, Alcaláde Henares, Madrid, Spain

e-mail: pilar.uria@uah.es
}

\section{Introduction}

It is widely acknowledged that soil temperature is one of the primary factors affecting plant growth in cool climates. In fact, soil temperature could be even more important than air temperature, because it usually lags behind (although it tracks) air temperature in spring (Pregitzer et al. 2000), as well as during diurnal temperature fluctuations (Bliss 1956). In seedlings of both broadleaved and conifer species, root growth is clearly constrained below $6^{\circ} \mathrm{C}$ (Alvarez-Uria and Körner 2007), similar to shoot growth (cf. Körner 2008), irrespective of species or their elevational preferences. A strong growth limitation in roots below $6^{\circ} \mathrm{C}$ has been reported by several other authors (e.g. Bilan 1967; Tranquillini 1973; Turner and Streule 1983; Vapaavuori et al. 1992; Iivonen et al. 1999; Wan et al. 1999; Domisch et al. 2001; Landhausser et al. 2001; Solfjeld and Johnsen 2006), although some minute root extension may be seen at lower positive temperatures (e.g. in Betula; Alvarez-Uria and Körner 2007). Cold soils are thus likely to co-determine the distributional limit of plants at high latitude or high elevations, and this limit should occur at lower latitude or elevation in trees compared with low-stature plants, because trees, unlike low-stature plants, are more closely coupled aerodynamically to free atmospheric convection and restrict soil heat flux by shading (and thus cooling) their own rooting zone (Körner 1998; Körner et al. 2003; Körner and Paulsen 2004). Consequently, crowns and roots experience temperatures very similar to air temperature. In contrast, low stature plants "engineer" their own, warmer microclimate and exhibit more flexible and mostly shorter leaf duration and, thus, are able to grow at much higher elevations than trees can.

The expansion of a plant's root system does not only depend on the amount of biomass invested in roots, but it 
also depends on the way biomass is invested (e.g. the spatial arrangement of the root system) and the cost incurred in the construction of a given root length (specific root length, SRL $\left.\mathrm{m} \mathrm{g}^{-1}\right)$. SLR is a measure of the amount of dry matter a plant invests to forage for soil resources and it has been shown that plants with larger SLR ("cheaper" roots) are more vigorously growing (Ryser and Eek 2000). In a field study, Comas and Eissenstat (2004) found that roots of fast-growing tree species had higher SRL, smaller diameters, greater degree of branching than those of slow-growing species, suggesting faster soil exploration by more vigorous species. In growth chamber conditions, one-year-old seedlings of tree species belonging to three plant families showed greater SRL (and thinner roots) in the faster growing species across families (Comas et al. 2002).

The variability of morphological traits in roots, including SRL, under different environmental conditions has been studied by several authors. Short roots of Picea abies and Pinus sylvestris have been found to be thicker than those of Betula pendula (Ostonen et al. 2007a). In the same study, mean length, mass and volume of root tips decreased in the order Picea abies $>$ Pinus sylvestris $=$ Betula . pendula, while root tip frequency per unit dry mass was significantly higher in Betula than in Picea and Pinus. Across season, soil depth, and order, roots of Larix gmelinii were generally found to be significantly thicker and longer, have lower SRL and higher tissue density, than roots of Fraxinus mandshurica in Northeastern China (Wang et al. 2006).

Few studies have explored the influence of low soil temperature on SRL. Root diameter was found to be smaller in cold-adapted populations of marsh plants compared with warm-adapted plants (Chapin, 1974). Alpine forbs were reported to exhibit thinner roots and a higher SRL compared with low-altitude forbs (Körner and Renhardt 1987). Higher SRL and, thus, more efficient investment of carbon for spatial soil exploration, was considered to compensate for the lower physiological availability of water and nutrients in cold habitats (Chapin 1974) or as a compensation for poorer mycorrhization (Körner 1998). However, seedlings of six typical treeline and lowland tree taxa did not exhibit any significant differences in SRL between cold and warm substrate when grown under controlled conditions (AlvarezUria and Körner 2007). Among the studied taxa, the SRL of broadleaved seedlings was always higher than that of conifers at all root temperatures. Thus, broadleaved species had longer roots per unit root mass in those seedlings. Different responses to life in the cold may be seen in situ and in mature trees rather than seedlings, given that there is a clear differentiation in root traits in situ between lowland and alpine taxa in herbaceous species (Körner and Renhardt 1987).

In assessing the linkage between root architecture and function, root branching order is a functionally more appropriate criterion for standardised comparisons among taxa than root diameter classes (Eissenstat and Achor, 1999; Wang et al. 2006, Guo et al. 2008, Valenzuela-Estrada et al. 2008, Comas and Eissenstat 2009). However, branching order cannot be obtained from root samples extracted from soil cores, but requires root excavation. According to Guo et al. (2008), the finest two orders are primarily serving water and nutrient acquisition, with the third order typically being transitional between the predominant functions of absorption versus transport and anchorage.

The objective of the present investigation was to study in situ patterns of root structure, particularly SRL, in adult trees along elevational gradients. We expected that mature trees that live at high elevation (upper montane and treeline sites) have a higher SRL when compared to trees living at lower elevation, both across and within the species.

\section{Materials and methods}

We investigated 8 tree taxa, all belonging to genera frequently found in both lowland and high elevation sites: Alnus glutinosa (L.) Gaertn. (Ag), Alnus viridis (Chaix) DC. (Av), Larix decidua Mill. V(Ld), Pinus sylvestris L.(Ps), Pinus mugo Turra (Pm), Picea abies (L.) H.Karst. (Pa), Salix species (Ss) and Sorbus aucuparia L. (Sa). We collected roots from six pairs of elevationally distinct congeneric groups of trees (Alnus, Larix, Picea, Pinus, Salix, Sorbus) in Switzerland (Table 1) during July and August 2001. At each site, 4-5 individual trees (mostly 5) per genera, and two 3rd order root segments per individual were sampled from different locations within a few hundred meters distance (mostly 10 trees, yielding a total of 54 trees). In the mountain regions explored here, there is an obvious dominance of conifers and two genera of angiosperms (Alnus, Betula) at highest elevation, hence the relatedness of taxa with elevation may incur a phylogenetic bias that limits extrapolations to other floristic regions.

All sampling locations had well-developed humid soils and water-logged areas were avoided. All sampled trees grew on locations with full ground cover, either by neighboring trees (mostly) or by adjacent shrub or grass vegetation. So roots were faced with a natural competitive situation.

The soil surface near each sampling tree (within about one meter from the stem) was carefully removed with a shovel and by hand in order to search for root tips. Once a root tip was found, the associated root and its ramifications were excavated back from the tips to the base of a 3rd order root, in order to obtain a complete fraction of a given tree's root system. We considered fine unbranched terminal roots as first order and those at the next level of branching as second order (Fitter 1982). As root properties change with age (from tip to base), we always compared the youngest 
Table 1 Sampling sites, tree species and climate

\begin{tabular}{|c|c|c|c|c|c|c|c|}
\hline Site & Coordinates & Elevation & $\begin{array}{l}\text { Growing season } \\
\text { (months) }\end{array}$ & $\begin{array}{l}\text { Annual mean } \\
\text { temperature }\left({ }^{\circ} \mathrm{C}\right)\end{array}$ & $\begin{array}{l}\text { Growing season mean } \\
\text { temperature }\left({ }^{\circ} \mathrm{C}\right)\end{array}$ & $\begin{array}{l}\text { Precipitation } \\
(\mathrm{mm})\end{array}$ & Species \\
\hline \multicolumn{8}{|l|}{ Lowland } \\
\hline Binningen & $47^{\circ} 53^{\prime} \mathrm{N}, 7^{\circ} 59^{\prime} \mathrm{E}$ & 320 & 6 & 9.9 & 15.5 & 803 & $\mathrm{Ag}, \mathrm{Pa}, \mathrm{Sa}, \mathrm{Ss}$ \\
\hline Hoffstetten & $47^{\circ} 46^{\prime} \mathrm{N}, 7^{\circ} 50^{\prime} \mathrm{E}$ & 550 & 6 & 8.6 & 13.3 & 963 & $\mathrm{Ld}$ \\
\hline Gempen & $47^{\circ} 48^{\prime} \mathrm{N}, 7^{\circ} 67^{\prime} \mathrm{E}$ & 700 & 5 & 7.3 & 15.9 & 968 & Ps \\
\hline \multicolumn{8}{|l|}{ Montane } \\
\hline Davos & $46^{\circ} 78^{\prime} \mathrm{N}, 9^{\circ} 87^{\prime} \mathrm{E}$ & 1,590 & 4 & 3.8 & 10.5 & 1,206 & $\mathrm{Sa}$ \\
\hline \multicolumn{8}{|l|}{ Treeline } \\
\hline Gafia & $46^{\circ} 97^{\prime} \mathrm{N}, 9^{\circ} 82^{\prime} \mathrm{E}$ & 1,800 & 4 & 2.5 & 9.2 & 1,244 & Ss \\
\hline Trübsee & $46^{\circ} 80^{\prime} \mathrm{N}, 8^{\circ} 38^{\prime} \mathrm{E}$ & 1,800 & 4 & 2.1 & 8.8 & 1,796 & $\mathrm{~Pa}$ \\
\hline Aschariner Alp & $46^{\circ} 97^{\prime} \mathrm{N}, 9^{\circ} 82^{\prime} \mathrm{E}$ & 1,950 & 4 & 1.7 & 8.4 & 1,244 & Av \\
\hline Stillberg & $46^{\circ} 78^{\prime} \mathrm{N}, 8^{\circ} 38^{\prime} \mathrm{E}$ & 2,235 & 3 & 0.3 & 7.3 & 1,206 & Pm, Ld \\
\hline
\end{tabular}

Sites are sorted by mean growing season mean air temperature and tree species and climate data (for full species names see Methods). The length of the growing season period represents, approximately, the snow free period

root fraction, from the base of a 3rd order root, including all second and first order roots which ramified from it. Sampled roots were washed with tap water and immediately stored in formaldehyde ( $10 \%$ vol) for further analysis. Final cleaning of roots was performed over a $2 \mathrm{~mm}$ mesh sieve in water in the laboratory.

Total root length and mean root diameter per sample were calculated from 600-dpi scans (Epson Expression 1680 scanner, Epson, Meerbusch), using the software Rootedge 2.3b (Iowa State University Research Foundation, Inc., Ames, IA, USA, 2001). For scanning roots, they were placed in a transparent water filled tray to facilitate root spreading. Finally, all samples were dried to constant weight at $80^{\circ} \mathrm{C}$ and weighed. Specific root length was calculated by dividing root length $(\mathrm{m})$ by root dry weight $(\mathrm{g})$, for the whole root segment (from tips to the base of a 3rd order root).

We also made morphological analysis in order to explain trends in SRL. We measured root diameter at the base of the 3 rd order root under a dissecting microscope. Further, we recorded root length from this point to the main tip, as well as the total number of root tips of each root fraction sampled. Root tips $<0.5 \mathrm{~mm}$ in length were considered a separate category (not included in branching order 1). This morphological analysis was done in two root segments per tree, and two morphological ratios where calculated by (1) dividing root length (maximum distance from base to the main tip) by root diameter and (2) by dividing the total number of tips by root length.

Elevation (low and high) and genera effects were tested using two-way ANOVA. Effects were considered significant if $P<0.05$. A Tukey-Kramer test was used for multiple comparisons. To ensure homogeneity of variance and normal distribution, data were transformed using logarithm.
All the analyses were performed with the software jmp 9 (SAS Institute, Inc., Cary, NC, USA).

\section{Results}

Specific root length (SRL)

Across the taxa examined, there were no significant differences in SRL between high- (treeline and montane), and low-elevation sites (Table 2a, Fig. 1a). However, genera differed in SRL, and there was no significant interaction between altitude and genera (Table 2a). SRL was generally higher in broad-leaved than in conifer species: Salix, Sorbus and Alnus showed particularly high SRL (i.e. thin roots). Pinus and Picea showed the lowest SRL. Thus, most broad leaved genera exhibited greater root length per unit root mass, irrespective of elevation. There was also no elevational trend if taxa or conifer versus deciduous genera were tested separately.

\section{Root diameter}

There was also no significant difference in root diameter between high-(treeline and montane), and low-elevation sites (Table 2b, Fig. 1b), but genera differed significantly and there was no significant interaction between the altitude and genera (Table 2b). Salix, and Sorbus showed the thinnest roots, thus confirming the SLR data.

\section{Ratio of root length to root diameter}

Concerning the ratio between total root length and root diameter at the base of 3rd-order roots, there were significant 
Table 2 Results of two-way ANOVAs for specific root length (SRL), root diameter, the ratio between root length and root diameter at the base of 3rd order roots, and the ratio between the number of tips and root length for elevation (low and high elevation sites) and genera

\begin{tabular}{|c|c|c|c|}
\hline Source of variation & $d f$ & $F$ & $p$ \\
\hline \multicolumn{4}{|l|}{ a) SRL } \\
\hline Elevation & 1 & 0.09 & 0.77 \\
\hline Genera & 5 & 35.74 & $<0.01$ \\
\hline Interaction & 5 & 0.96 & 0.45 \\
\hline Error & 42 & & \\
\hline Total & 54 & & \\
\hline \multicolumn{4}{|l|}{ b) Root diameter } \\
\hline Elevation & 1 & 3.56 & 0.07 \\
\hline Genera & 5 & 13.56 & $<0.01$ \\
\hline Interaction & 5 & 1.81 & 0.13 \\
\hline Error & 42 & & \\
\hline Total & 54 & & \\
\hline \multicolumn{4}{|c|}{ c) Root length/root diameter } \\
\hline Elevation & 1 & 4.15 & 0.48 \\
\hline Genera & 5 & 0.05 & $<0.01$ \\
\hline Interaction & 5 & 2.94 & 0.02 \\
\hline Error & 42 & & \\
\hline Total & 54 & & \\
\hline \multicolumn{4}{|c|}{ d) Number of tips/root length } \\
\hline Elevation & 1 & 15.55 & $<0.01$ \\
\hline Genera & 5 & 2.74 & 0.03 \\
\hline Interaction & 5 & 6.86 & $<0.01$ \\
\hline Error & 42 & & \\
\hline Total & 54 & & \\
\hline
\end{tabular}

differences among the genera and a significant interaction between the elevation and genera (Table 2c). This was because the broadleaved species had a higher ratio at high elevation (upper montane and treeline sites) when compared with conifers, but there were no differences between these two groups in the lowland sites (Fig. 2a). These results indicate that broadleaved species at high elevation exhibit longer roots per basal diameter than low-elevation broadleaved species (one-way ANOVA, $F(1,28)=16.87$, $p<0.001)$, a difference not seen in conifers.

\section{Root tips per root length}

There were significant differences among the genera and between the elevations, and a significant interaction between the elevation and genera in the ratio between the number of tips and root length (Table 2d, Fig. 2b). Generally, Larix had the highest number of root tips per root length, followed by Salix. In the lowland, Alnus had also a high number or root tips per root length, but at the treeline this genera had the lowest value of this morphological trait. Sorbus showed the

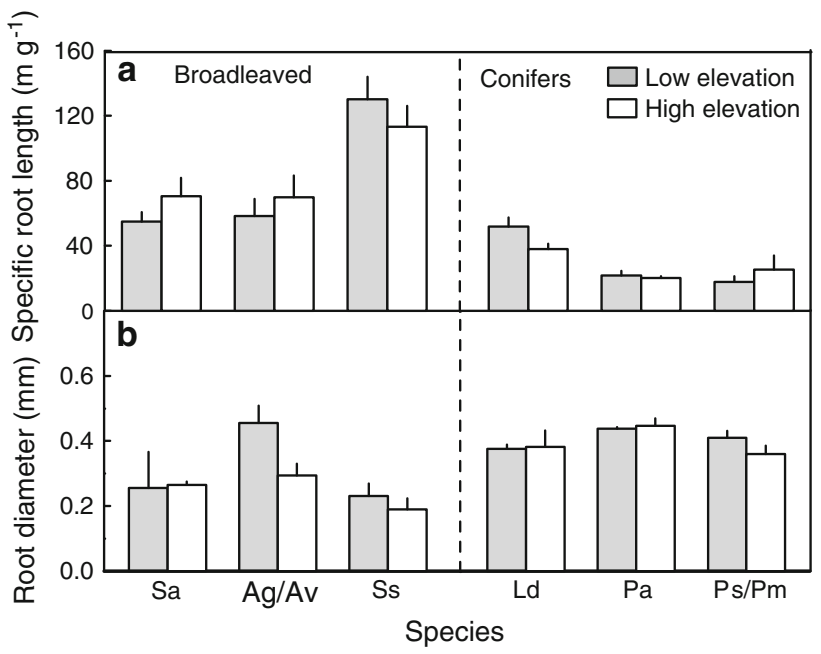

Fig. 1 Effects of plant functional type and elevation on mean (+SE) specific root length and root diameter of complete fractions of root systems, excavated from the tip to base of 3 rd order roots in six genera ( 5 trees per species and site for the genera studied at both elevations $n=54$ trees; Ag, Alnus glutionsa; Av, A.viridis; Sa, Salix atrocinerea; Ss, Salix species; Sa, Sorbus aucuparia; Ld, Larix decidua; Pa, Picea abies; Ps, Pinus sylvestris; Pm, P. mugo)

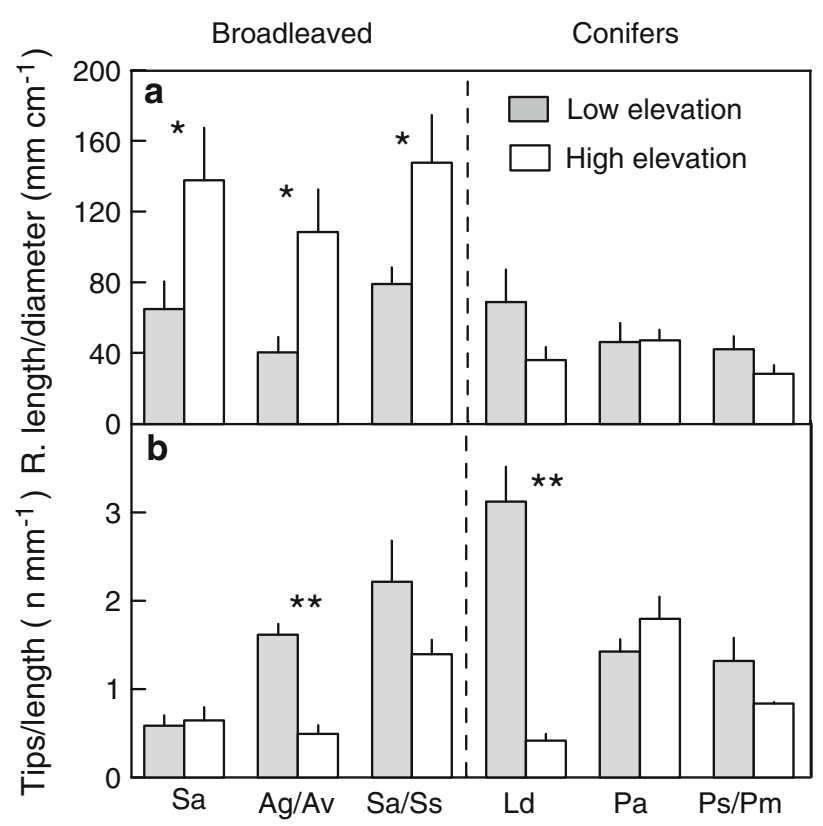

Fig. 2 Effects of plant functional type and elevation on mean $( \pm \mathrm{SE})$ ratio of root length per diameter and root tips per root length, separated by plant functional type and elevation (low elevation versus high elevation sites, montane and treeline sites pooled) in six genera. 5 trees per species and site for the genera studied at both elevations ( $n=54$ trees; Ag, Alnus glutionsa; Av, A.viridis; Sa, Salix atrocinerea; Ss, Salix species; Sa, Sorbus aucuparia; Ld, Larix decidua; $\mathrm{Pa}$, Picea abies; $\mathrm{Ps}$, Pinus sylvestris; $\mathrm{Pm}, P$. mugo; $P<0.01$ (double asterick); $P<0.05$ (asterick))

significantly lowest number of tips per root length if treeline and lowland sites were taken together. When each genus was analysed separately for elevation effects, only Larix and 
Alnus showed significant differences with a higher number or tips per root length in the lowland.

\section{Discussion}

Across three treeline, one montane and four lowland sites from elevations ranging from 320 masl to 2,235 masl, no elevational differences were found in SRL, for both broadleaved and conifer tree species. Thus, the low- and highelevation taxa, as a group, did not reveal any consistent differences in this trait. Irrespective of elevation preference of taxa, SRL of evergreen conifers was significantly lower than that of deciduous species (with the exception of Larix, which is more like the deciduous broadleaved taxa). Salix has an extraordinarily high SRL and very thin roots. It is to be explored, whether this contributes to the success of this woody genus at very high elevation and polar latitudes worldwide. Our findings clearly demonstrate that high SRL is not an essential attribute of tree existence at high elevations in the Alps. Acer, Betula, Fagus, Fraxinus and Quercus also do not show differences in SRL in relation to elevation in the Cantabrian Mountains of northwestern Spain (P. Alvarez-Uria, unpublished data).

These in situ findings for adult trees are in agreement with the results of our earlier study with seedlings under controlled conditions (Alvarez-Uria and Körner 2007), which did not reveal any differences in SRL for seedlings grown at $6^{\circ} \mathrm{C}$ or $16^{\circ} \mathrm{C}$. Thus, there is neither long- nor short-term change in dry matter investment per unit of root length for soil exploration in cold versus warm soils, and in both, juvenile and adult individuals. It appears that SRL in the studied tree species is a rather conservative trait. The other morphological traits (in our case the root thickness data) match the SRL data. The only trend with elevation is the observed increase in total root length for a given 3rd-order root diameter in the broadleaved taxa at high elevation. Hence, in this group of species the total (accumulative) length of root systems is $54 \%$ bigger in the colder sites. The higher SRL in broadleaved compared to conifer species is consistent with the findings of Reich et al. (1998); Bauhus and Messier (1999); Pregitzer et al. (2002); Ostonen et al. (2007b). The differences in SRL among species documented in the present work support the view that SRL is associated with tree life-history traits (Reich et al. 1998).

The current work explored root-specific traits. Total root system traits (whole plant level) would require knowledge about total fine root mass and length for complete individuals and information on root longevity, both not available and not easy to obtain for the trees examined here. There is some indication that the annual rate of root length growth is reduced at high elevation (Graefe et al.2008, for tropical mountain forests), and following the global trends compiled by Gill and jackson (2000) one would expect slower root turnover at high elevation, which by itself would enhance the fine root fraction (longer root duration). Bernoulli and Körner (1999) found no overall elevational change in the root mass fraction for three conifer species growing near the treeline. In one species (Pinus uncinata) there was even a declining trend.

Overall, the results of this study do not support the hypothesis that tree roots are generally becoming more efficient in terms of dry matter invested per length or length per diameter as elevation increases in the Alps. Yet, in the subgroup of deciduous species such a trend for longer roots is evident, although this does not significantly affect the SRL. The data are fairly consistent within each plant functional group and match our observations from controlled environment tests with seedlings where these root traits were unresponsive to soil temperature (Alvarez-Uria and Körner 2007). The exceptional patterns seen in Salix (extremely high SRL; many high alpine and arctic species) point at potential adaptive signals that deserve further exploration. We conclude that should there be an elevational adjustment of tree fine root traits across taxa, it is not specific root length and root diameter which contribute to such a change in our test region. Fine root longevity and/or overall tree fine root fraction per tree are potential candidates for such elevational adjustments.

Acknowledgments This study was funded by a Postdoctoral Grant from the Secretary of Education and Universities of the Ministry of Education and Culture, Spain (EX 2001 09407386). We are grateful to Jürg Stöcklin for helpful comments on the text, and to Susanna Riedl and Jens Paulsen for technical help.

\section{References}

Alvarez-Uria P, Körner Ch (2007) Low temperature limits of root growth in deciduous and evergreen temperate tree species. Funct Ecol 21:211-218

Bauhus J, Messier C (1999) Soil exploitation strategies of fine roots in different tree species of the southern boreal forest of eastern Canada. Can J For Res 29:260-273

Bernoulli M, Körner Ch (1999) Dry matter allocation in treeline trees. Phyton 39:7-12

Bilan MV (1967) Effect of low temperature on root elongation in loblolly pine seedlings. Proceedings of the 14th IUFRO Congress. München 4(23):74-82

Bliss LC (1956) A comparison of plant development in microenvironments of arctic and alpine tundra. Ecol Monogr 36:303-337

Chapin FS III (1974) Morphological and physiological mechanisms of temperature compensation in phosphate absorption along a latitudinal gradient. Ecology 55:1180-1198

Comas LH, Eissenstat DM (2004) Linking fine root traits to maximum potential growth rate among 11 mature temperate tree species. Funct Ecol 18:388-397

Comas LH, Eissenstat DM (2009) Patterns in root trait variation among 25 co-existing North American forest species. New Phytol 182:919-928 
Comas LH, Bouma TJ, Eissenstat DM (2002) Linking root traits to potential growth rate in six temperate tree species. Oecologia 132:4-34

Domisch T, Finér L, Lehto T (2001) Effects of soil temperature on biomass and carbohydrate allocation in Scots pine (Pinus sylvestris) seedlings at the beginning of the growing season. Tree Physiol 21:465-472

Eissenstat DM, Achor DS (1999) Anatomical characteristics of roots of Citrus rootstocks that vary in specific root length. New Phytol 141(2):309-321

Fitter AH (1982) Morphological analysis of root systems: application of the technique and influence of soil fertility on root system development in two herbaceous species. Plant Cell and Environment 5:313-322

Gill R, Jackson R (2000) Global patterns of root turnover for terrestrial ecosystems. New Phytol 147:13-31

Graefe S, Hertel D, Leuschner C (2008) Estimating fine root turnover in tropical forests along an elevational transect using minirhizotrons. Biotropica 40(5):536-542

Guo DL, Xia M, Wei X, Chang W, Liu Y, Wang Z (2008) Anatomical traits associated with absorption and mycorrhizal colonization are linked to root branch order in twenty-three Chinese temperate tree species. New Phytol 180:673-683

Iivonen S, Rikala R, Ryyppö A, Vapaavuori E (1999) Responses of Scots pine (Pinus sylvestris) seedlings grown in different nutrient regimes to changing root zone temperature in spring. Tree Physiol 19:951-958

Körner Ch (1998) A re-assessment of high elevation treeline positions and their explanation. Oecologia 115:445-459

Körner Ch (2008) Winter crop growth at low temperature may hold the answer for alpine treeline formation. Plant Ecol and Divers 1(1):3-11

Körner Ch, Paulsen J (2004) A world-wide study of high altitude treeline temperatures. J Biogeogr 31:713-732

Körner Ch, Renhardt U (1987) Dry-matter partitioning and root length leaf-area ratios in herbaceous perennial plants with diverse altitudinal distribution. Oecologia 74:11-418

Körner Ch, Paulsen J, Pelaez-Riedl S (2003) A bioclimatic characterisation of Europe's alpine areas. In: Nagy L, Grabherr G, Körner C, Thompson DBA (eds) Alpine Biodiversity in Europe. Springer, Berlin, pp 13-28

Landhausser SM, DesRochers A, Lieffers VJ (2001) A comparison of growth and physiology in Picea glauca and Populus tremuloides at different soil temperatures. Can J For Res 31:1922-1929

Ostonen I, Lohmus K, Helmisaari H, Truu J, Meel S (2007a) Fine root morphological adaptations in Scots pine, Norway spruce and silver birch along a latitudinal gradient in boreal forests. Tree Physiol 27:1627-1634

Ostonen I, Püttsepp U, Biel C, Alberton O, Bakker MR, Lohmus K, Majdi H, Metcalfe D, Olsthoorn AFM, Pronk A, Vanguelova E, Weih M, Bruner I (2007b) Specific root length as an indicator of environmental change. Plant Biosystems 141(3):426-442

Pregitzer KS, King JS, Andrew JB, Brown E (2000) Responses of tree fine roots to temperature. New Phytol 147:105-115

Pregitzer KS, DeForest JL, Burton AJ, Allen MF, Ruess RW, Hendrick RL (2002) Fine root architecture of nine north American trees. Ecol Monogr 72:293-309

Reich PB, Walters MB, Tjoelker G, Vanderklein D, Buschena C (1998) Photosynthesis and respiration rates depend on leaf and root morphology and nitrogen concentration in nine boreal tree species differing in relative growth rate. Funct Ecol 12: 395-405

Ryser P, Eek L (2000) Consequences of phenotypic plasticity versus interspecific differences in leaf and root traits for acquisition of aboveground and belowground resources. Am J Bot 87:402-441

Solfjeld I, Johnsen $\varnothing$ (2006) The influence of root-zone temperature on growth of Betula pendula Roth. Trees 20:320-328

Tranquillini W (1973) Der Wasserhaushalt junger Forstpflanzen nach dem Versetzen und seine Beeinflussbarkeit. Cbl ges. Forstw 90:46-52

Turner H, Streule A (1983) Wurzelwachstum und Sprossentwicklung junger Koniferen im Stressklima der alpinen Waldgrenze, mit Berücksichtigung von Mikroklima, Photosynthese und Stoffproduktion. In: Böhm W, Kutschera L, Lichtenegger E (eds) Wruzelökolgie und ihre Nutzanwendung. Bundesanstalt für alpenländische Landwirtschaft, Gumpenstein

Valenzuela-Estrada LR, Vera-Carballo V, Leah ER, Eissenstat DM (2008) Root anatomy, morphology, and longevity among root orders in Vaccinium corymbosum (Ericaceae). Am J Bot 95(2): $1506-1514$

Vapaavuori EM, Rikala R, Ryyppö A (1992) Effects of root temperature on growth and photosynthesis in conifer seedlings during shoot elongation. Tree Physiol 10:217-230

Wan XC, Landhausser SM, Zwiazek JJ, Lieffers VJ (1999) Root water flow and growth of aspen (Populus tremuloides) at low root temperatures. Tree Physiol 19:879-884

Wang Z, Guo D, Wang X, Gu J, Mei L (2006) Fine root architecture, morphology, and biomass of different branch orders of two Chinese temperate tree species. Plant Soil 288:155-171 